\title{
Aplikasi Penjualan Mebel Titik Cerah Berbasis Android
}

\author{
Haryanto*1, Ernes Cahyo Nugroho $^{2}$, Afifah Nur Pratiwi ${ }^{3}$ \\ ${ }^{1}$ Program Studi Sistem Komputer; ${ }^{2}$ Program Studi Sistem Komputer; \\ ${ }^{3}$ Program Studi Sistem Informasi \\ ${ }^{123}$ STMIK AUB Surakarta, Indonesia \\ e-mail: *11haryanto@stmik-aub.ac.id, ${ }^{2}$ ernes.cahyo@stmik-aub.ac.id, ${ }^{3}$ afifahn@gmail.com
}

\begin{abstract}
Abstrak
Mebel merupakan salah satu produk kayu olahan yang pertumbuhannya amat pesat dalam beberapa waktu terakhir ini. Tidak efektif dan efisiennya pelanggan atau konsumen pergi ke toko mebel Titik Cerah dikarenakan memerlukan waktu dan biaya. Pelanggan harus jauh jauh atau bisa saja tidak tahu tempat toko mebel Titik Cerah jadinya harus bertanya ke orangorang dahulu dan memerlukan biaya untuk membeli bensin pada kendaraannya. Tujuan penelitian ini adalah untuk memudahkan pelanggan/konsumen membeli/memesan produk tanpa mendatangi toko mebel dan pada web untuk memudahkan pemilik mengelola data kategori, data produk mebel, pemesanan, laporan data produk, laporan data pemesanan dan laporan data penjualan. Hasil dari penelitian ini adalah membuat suatu aplikasi penjualan mebel berbasis Android, untuk meningkatkan kualitas penjualan mebel, dan mengurangi waktu maupun biaya karena pelanggan dapat menggunakan aplikasi dimanapun dan kapanpun. Aplikasi tersebut menggunakan metode waterfall, database MySQL, Android Versi 3.1.
\end{abstract}

Kata kunci: Aplikasi, Android, Penjualan, Mebel

\section{PENDAHULUAN}

Perkembangan teknologi pada handphone sekarang sudah berkembang dengan menggunakan teknologi sistem operasi android yang memungkinkan penggunaan handphone untuk membuat aplikasi berbasis android. Pengguna dapat melakukan kreasi pada telepon selularnya atau dengan men-download aplikasi android untuk selanjutnya digunakan pada handphone mereka. Teknologi handphone juga digunakan untuk penjualan mebel pada jaman sekarang, untuk mempermudahkan pelanggan atau konsumen membeli produk mebel. Mereka sering menggunakan handphone untuk mencari mebel sesuai kebutuhan.

Mebel merupakan salah satu produk kayu olahan yang pertumbuhannya amat pesat dalam beberapa waktu terakhir ini. Berawal dari pekerjaan rumah tangga, produk mebel kini telah menjadi industri yang cukup besar dengan tingkat penyerapan tenaga kerja terdidik yang tidak sedikit. Produk jenis ini secara prinsip dibagi dalam dua kategori yaitu mebel untuk taman (garden) dan interior dalam rumah.

Mebel untuk perlengkapan rumah merupakan salah satu bidang usaha yang menguntungkan, karena pertumbuhan penduduk semakin hari semakin meningkat, sehingga kebutuhan akan tempat tinggal pun semakin tinggi, yang otomatis berdampak kepada meningkatnya kebutuhan akan peralatan rumah tangga salah satunya mebel.

Begitupun dengan Mebel Titik Cerah di Banjarsari Solo ada peminatnya walaupun tidak terlalu banyak. Kegiatan penjualan barang yang berjalan selama ini ada dua cara yaitu langsung dan tidak langsung. Secara langsung yaitu pembelian mebel yang sudah jadi, cara kedua yaitu memesan dengan harga yang variatif sesuai dengan rancangan dan bahan sesuai selera konsumen dengan ketentuan semakin bagus rancangan, ukuran, model, dan semakin bagus bahan kayu yang digunakan maka akan semakin mahal, untuk kayu yang digunakan 
adalah jati, jati tua, akasia dan waktu pemesanan hampir 2 minggu, harus menyerahkan uang muka (uang dp) terlebih dahulu.

Mebel Titik Cerah beralamat di Jln. A Yani No 67 Bibis Kulon 02/18, Gilingan, Banjarsari Solo, berdiri sejak tahun 1985. Tidak efektif dan efisiennya pelanggan atau konsumen pergi ke toko mebel Titik Cerah dikarenakan memerlukan waktu dan biaya. Pelanggan harus jauh - jauh atau bisa saja tidak tahu tempat toko mebel Titik Cerah jadinya harus bertanya ke orang - orang dahulu dan memerlukan biaya untuk membeli bensin pada kendaraannya.

Pada Toko mebel Titik Cerah tersebut yang diperjualkan mebel yang sudah setengah jadi, dikarenakan pembuatan mebel di Jepara, ditoko tersebut cuma tahap finishing terhadap kayu. Bahan pembuatan mebel menggunakan kayu jati, jati tua, dan akasia. Proses pembelian di toko mebel Titik Cerah adalah pelanggan datang, memilih mebel, menanyakan harga mebel yang sudah dipilih, kalau benar membeli mebel yang dipilih, bisa langsung dibayar lunas atau bisa juga memakai uang muka / kredit. Pelanggan harus banyak bertanya kepada pemilik dikarenakan tidak adanya katalog yang berisi foto mebel, harga mebel, stok, bahan mebel, pengiriman mebel, pembayaran mebel, cara memesan.

Berdasarkan permasalahan di atas maka akan dibuat suatu aplikasi penjualan mebel berbasis Android. Proses aplikasi android yaitu pelanggan atau konsumen memilih kategori, selanjutnya memilih produk mebel, setelah itu klik beli dan mengisi berapa jumlah yang akan dibeli, lalu mengisi form pemesanan, sesudah mengisi form pemesanan klik kirim, dan langsung melihat total pembayaran dan ongkos kirim untuk ditransfer di no rekening yang sudah ada di aplikasi tersebut. Dengan adanya aplikasi ini, diharapkan mampu meningkatkan kualitas penjualan mebel, dan mengurangi waktu maupun biaya karena pelanggan dapat menggunakan aplikasi dimanapun dan kapanpun. Aplikasi tersebut menggunakan metode waterfall.

Berdasarkan uraian yang dikemukakan diatas, penulis memandang perlu untuk membuat sebuah aplikasi sebagai bahan skripsi dengan judul "Aplikasi Penjualan Mebel Titik Cerah Berbasis Android".

\section{METODE PENELITIAN}

\subsection{Metode Pengambilan Data}

1. Metode Wawancara

Wawancara digunakan sebagai teknik pengumpulan data apabila peneliti ingin melakukan studi pendahuluan untuk menemukan permasalahan yang harus diteliti, tetapi juga apabila peneliti ingin mengetahui hal-hal dari responden yang lebih mendalam. Sugiyono (2013).

Penulis melakukan wawancara dengan Ibu Titik Puspitawati selaku Pemilik Toko Mebel Titik Cerah Solo, bagaimana proses penjualan mebel dengan saingan yang banyak, cara pembayarannya, proses pembelian mebel, cara pengirimannya, omset penjualan mebel, dan cara pemasarannya ?, Apakah bisa menerima pesanan mebel sesuai permintaan konsumen ?, Mebel dibuat memakai kayu apa ?, Toko tersebut menjualkan apa saja ?, Pelanggan toko mebel didaerah mana saja ?, Berapa lama dan harganya berapa untuk memesan mebel yang belum jadi ?.

2. Metode Observasi

Dalam observasi peneliti terlibat dengan kegiatan sehari-hari orang yang sedang diamati atau yang digunakan sebagai sumber data penelitian.Sugiyono (2013).

Penulis melakukan observasi dan mengumpulkan data dengan mengamati secara langsung proses penjualan, proses pembayaran, proses pengiriman, proses pembelian, omset penjualan, menerima pesanan, proses pemasaran, memakai kayu apa untuk pembuatan mebel pada Toko mebel Titik Cerah ?.

3. Metode Pustaka

GO INFOTECH: JURNAL ILMIAH STMIK AUB Vol. 24, No. 2, Desember 2018 : 95 - 109 
Metode ini dilakukan dengan cara membaca atau mempelajari buku-buku referensi literature yang berhubungan dengan masalah yang akan dibahas guna memperoleh landasan teori untuk keperluan menganalisa data. Usman dan Akbar (2000).

Untuk memperkuat data-data dan masalah yang dihadapi, penulis mencari informasi lewat perpustakaan, internet, buku literatur serta jurnal sebagai referensi untuk melakukan kegiatan penelitian tersebut.

\subsection{Metode Waterfall}

Menurut Saputra dan Agustin (2012), perancangan sebuah aplikasi atau sistem memerlukan metode - metode dalam pembangunan atau pengembangan sistem. Metode Waterfal merupakan metode pengembangan perangkat lunak yang secara umum dilakukan oleh para peneliti sistem, melalui beberapa tahapan penelitian pada gambar 1 yaitu:

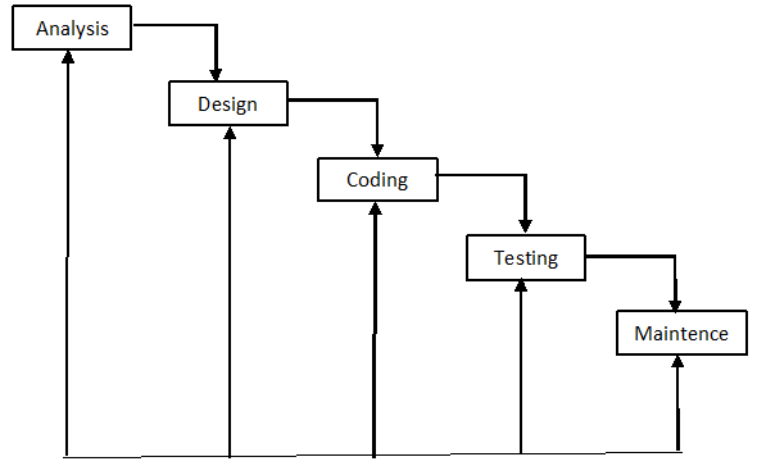

Gambar 1 Tahapan Metode Waterfall

a. Analysis

Tahap ini merupakan tahap dalam mencari informasi sebanyak -banyaknya mengenai sistem yang diteliti dengan melakukan metode - metode pengumpulan data sehingga ditemukan kelebihan dan kekurangan sistem serta user requirement. Tahap ini juga dilakukan untuk mencari pemecah masalah dan menganalisis bagaimana sistem akan dibangun untuk memecahkan masalah pada sistem sebelumnya.

b. Design

Tahap ini merupakan tahapan perancangan sistem, penulis melakukan beberapa hal perancangan sistem dengan menggunakan Flowchart, UML (Unified Modeling Language), Relasi Tabel, perancangan database dan perancangan desain sistem.

c. Coding

Tahap ini merupakan tahapan dalam pengimplementasian sistem yang sudah dirancang dan dilakukan pengujian secara unit, agar dapat mengetahui kesalahan - kesalahan yang terdapat dalam sistem dan segera dilakukan perbaikan.

d. Testing

Tahap ini merupakan tahap pengujian sistem secara keseluruhan. Tahap ini sistem yang akan dikembangkan menggunakan teknik pengujian black box

e. Maintenance

Tahap ini merupakan tahapan penggunaan sistem oleh user yang didalamnya harus ada pemeliharaan sistem untuk menjaga proses operasional sistem dan memungkinkan untuk dilakukan pengembangan sistem di kemudian hari.

\subsection{Black Box Testing}

Pengujian menggunakan sekumpulan aktifitas validasi, dengan pendekatan black box testing. Menurut Shalahuddin dan Rosa (2011), black box testing adalah menguji perangkat lunak dari segi spesifikasi fungsional tanpa menguji desain dan kode program. Pengujian dimaksudkan untuk mengetahui apakah fungsi - fungsi, masukan, dan keluaran dari perangkat lunak sesuai dengan spesifikasi yang dibutuhkan. Pengujian kotak hitam dilakukan dengan membuat kasus uji yang bersifat mencoba semua fungsi dengan 
memakai perangkat lunak apakah sesuai dengan spesifikasi yang dibutuhkan. Kasus uji yang dibuat untuk melakukan pengujian black box testing harus dibuat dengan kasus benar dan kasus salah.

Menurut Pressman (2010), black box testing juga disebut pengujian tingkah laku, memusat pada kebutuhan fungsional perangkat lunak. Teknik pengujian black box memungkinkan memperoleh serangkaian kondisi masukan yang sepenuhnya menggunakan semua persyaratan fungsional untuk suatu program. Beberapa jenis kesalahan yang dapat diidentifikasi adalah fungsi tidak benar atau hilang, kesalahan antar muka, kesalahan pada struktur data (pengaksesan basis data), kesalahan performasi, kesalahan inisialisasi dan akhir program.

a. Equivalence Partitioning

Equivalence Partitioning merupakan metode black box testing yang membagi domain masukan dari program kedalam kelas - kelas sehingga test case dapat diperoleh. Equivalence Partitioning berusaha untuk mendefinisikan kasus uji yang menemukan sejumlah jenis kesalahan, dan mengurangi jumlah kasus uji yang harus dibuat. Kasus uji yang didesain untuk Equivalence Partitioning berdasarkan pada evaluasi dari kelas ekuivalensi untuk kondisi masukan yang menggambarkan kumpulan keadaan yang valid atau tidak. Kondisi masukan dapat berupa spesifikasi nilai numerik, kisaran nilai, kumpulan nilai yang berhubungan atau kondisi boolean.

Kesetaraan kelas dapat didefinisikan menurut panduan berikut Pressman (2001) :

1) Jika masukan kondisi menentukan kisaran, satu sah dan dua diartikan tidak valid kesetaraan kelas.

2) Jika masukan membutuhkan nilai, kondisi tertentu satu sah dan dua tidak valid kesetaraan kelas diartikan.

3) Jika masukan kondisi menentukan anggota dari set, satu sah dan satu tidak valid kesetaraan kelas diartikan.

4) Jika kondisi yang input, boolean satu sah dan satu tidak valid kelas diartikan.

Beberapa kata kunci dalam pengujian perangkat lunak yang dapat diperhatikan, yaitu

(Simarmata, 2009) :

a) Dinamis

Pengujian perangkat lunak dilakukan pada masukan yang bervariasi. Masukan ini ditentukan sebelum pengujian dilakukan dengan batasan yang disesuaikan dengan kemampuan perangkat lunak. Masukan tidak harus sesuatu yang dimungkinkan terjadi pada penggunaan program lebih lanjut, melainkan meliputi keseluruhan batasan yang dapat dijangkau perangkat lunak dan dilakukan percontohan (sampling) secara acak untuk proses pengujian.

b) Terbatas

Meskipun pengujian dilakukan pada perangkat lunak sederhana sehingga rumit sekalipun, pengujian dilakukan dengan memenuhi batasan - batasan tertentu sesuai dengan kemampuan program. Batasan ini juga diberlakukan pada masukan - masukan yang dipilih untuk pengujian. Tidak semua kemungkinan masukan diujika pada perangkat lunak karena akan memakan waktu yang cukup panjang mengingat begitu banyaknya kemungkinan yang bisa terjadi. Untuk mengatasi hal ini, pemilihan masukan - masukan pada proses pengujian secara acak yang diperkirakan mampu memenuhi kebutuhan pengujian perangkat lunak akan dilakukan.

c) Tertentu

Pengujian dilakukan dengan batasan tertentu disesuaikan dengan harapan pada fungsi, respon, dan karakteristik perangkat lunak tersebut. Batasan tersebut akan disesuaikan dengan teknik - teknik pengujian yang ada. Pemilihan kriteria pengujian yang paling tepat merupakan hal yang kompleks. Dalam praktiknya, analisis risiko pengujian dan pengalaman terhadap pengujian - pengujian sejenis akan diperlukan.

d) Harapan

GO INFOTECH: JURNAL ILMIAH STMIK AUB Vol. 24, No. 2, Desember 2018 : 95 - 109 
Kata kunci ini memiliki keadaan - keadaan yang diharapkan, baik berupa respon sistem terhadap masukan maupun karakteristik responnya. Dalam hal ini, batasan - batasan hasil pengujian yang diharapkan harus ditentukan. Dengan demikian, dapat diketahui apakah perangkat lunak tersebut telah memenuhi hasil pengujian yang diharapkan atau memerlukan pembenahan kembali, baik berupa perbaikan maupun pengembangan perangkat lunak.

2.4 Analisis PIECES

Untuk mengidentifikasi masalah, maka harus dilakukan analisis terhadap ekonomi, pengendalian, efisiensi dan pelayanan atau juga sering disebut dengan analisis pieces. Adapaun pengertian dari analisis pieces sebagai berikut Al Fatta (2007) :

a. Analisis Kinerja Sistem (Performance)

Kinerja adalah suatu kemampuan sistem dalam menyelesaikan tugas dengan cepat sehingga sasaran dapat segera tercapai. Kinerja diukur dengan jumlah produksi (throughput) dan waktu yang digunakan untuk menyelesaikan perpindahan pekerjaan (responsetime).

b. Analisis Informasi (Information)

Informasi merupakan hal penting karena dengan informasi tersebut pihak manajemen (marketing) dan user dapat melakukan langkah selanjutnya.

c. Analisis Ekonomi (Economy)

Pemanfaatan biaya yang digunakan dari pemanfaatan informasi.Peningkatan terhadap kebutuhan ekonomis mempengaruhi pengendalian biaya dan peningkatan manfaat.

d. Analisis Pengendalian (Control)

Analisis ini digunakan untuk membandingkan sistem yang dianalisa berdasarkan pada segi ketepatan waktu, kemudahan akses dan ketelitian data yang diproses.

e. Analisis Efisiensi (Efficiency)

Efisiensi berhubungan dengan bagaimana sumber tersebut dapat digunakan secara optimal. Operasi pada suatu perusahaan dikatakan efisien atau tidak biasanya didasarkan pada tugas dan tanggung jawab dalam menyelesaikan kegiatan.

f. Analisis Pelayanan (Service)

Peningkatan pelayanan memperlihatkan kategori yang beragam. Proyek yang dipilih merupakan peningkatan pelayanan yang lebih baik bagi manajemen (marketing), user dan bagian lain yang merupakan simbol kualitas dari suatu sistem informasi.

\section{HASIL DAN PEMBAHASAN}

\subsection{Implementasi Program}

Dalam pembuatan aplikasi ini dibutuhkan suatu implementasi untuk menguraikan program dan analisis dari hasil program yang telah dibuat. Tujuan pembahasan ini adalah untuk mengetahui apakah program yang dibuat sudah bekerja seperti yang diharapkan atau belum. Berikut adalah proses pembahasan interface atau antarmuka program:

a. Antar Muka Halaman Utama Berbasis Android

1) Halaman Utama User 


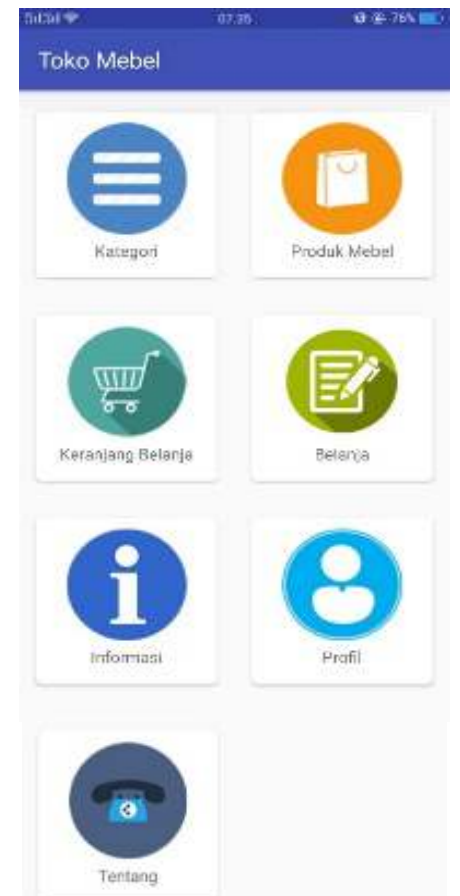

2) Halaman Kategori

Gambar 2 Halaman Utama User

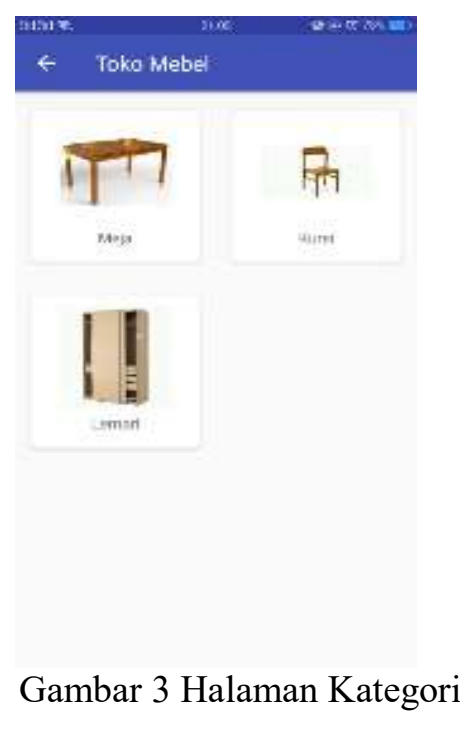

3) Halaman Produk 


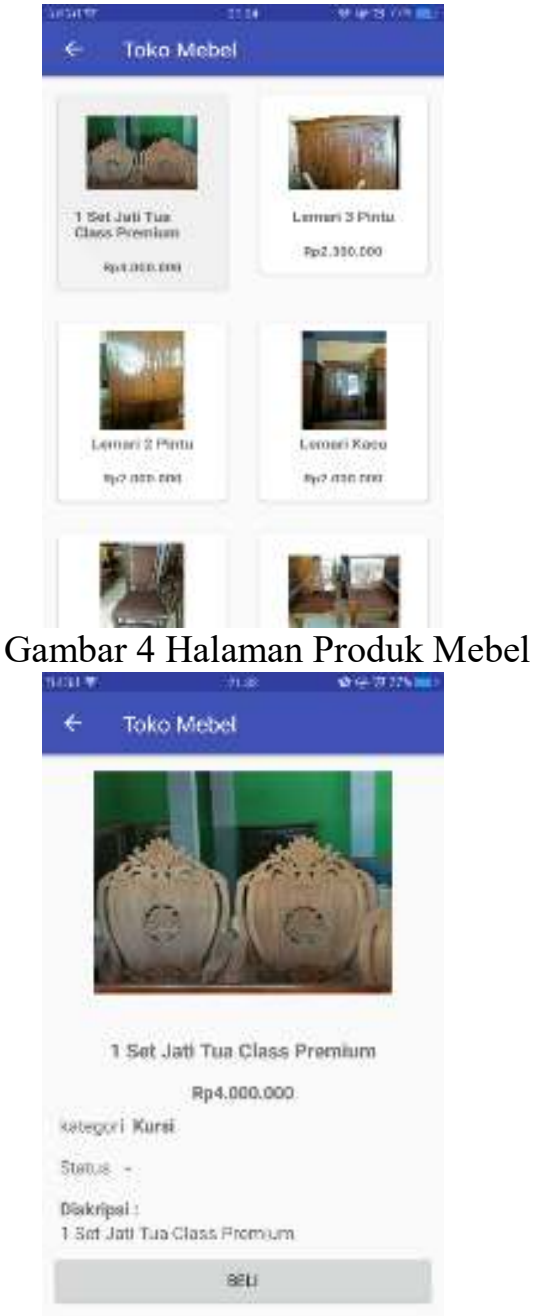

Gambar 5 Halaman Produk Mebel yang Dipilih

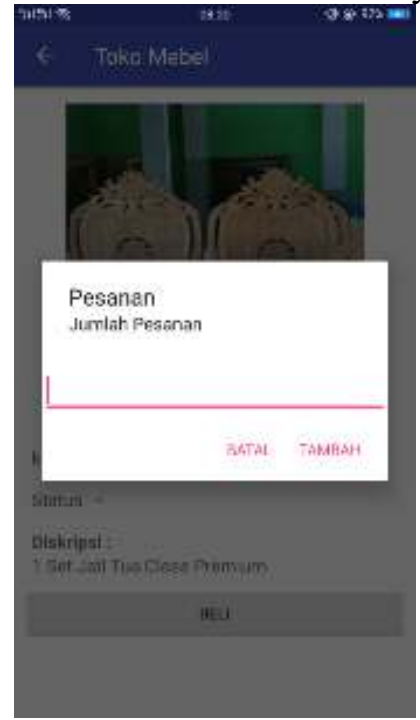

Gambar 6 Halaman Mengisi Jumlah Pesanan

Jika sudah masuk pada halaman produk, konsumen bisa memilih mebel yang akan dipilih, setelah itu diklik yang akan dipesan, lalu akan muncul mebel yang akan dipesan yang berisikan gambar, kategori, status, diskripsi, dan klik button beli, setelah itu diklik button beli, 
setelah diklik button beli, muncul jumlah pesanan, dimana konsumen harus menuliskan berapa jumlah pesanannya, lalu diklik button tambah, hasil pesanan yang dipilih akan masuk dihalaman keranjang belanja.

4) Halaman Keranjang belanja
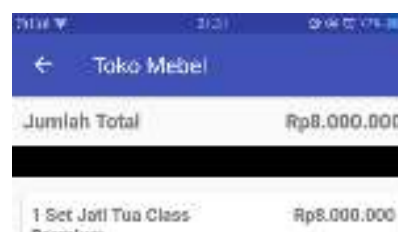

Prsmlum

Ap 8.000 .000

Rpécenocen

20

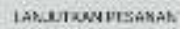

Gambar 7 Halaman Keranjang Belanja

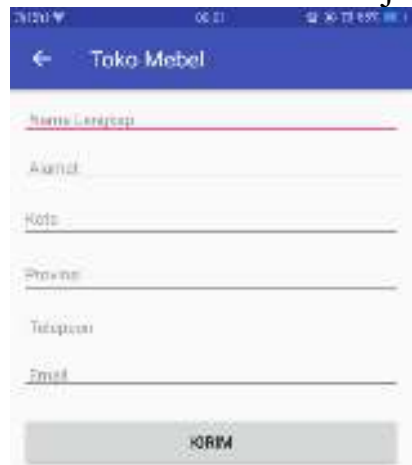

Gambar 8 Halaman Form pemesanan 


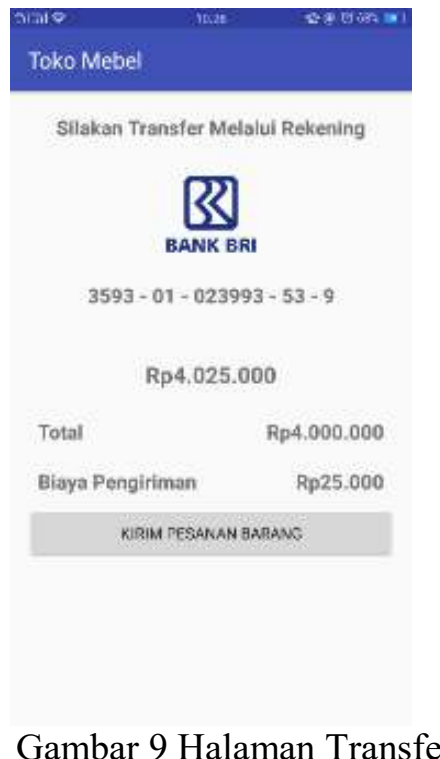

Setelah konsumen memilih pesanan, akan ada jumlah total pembayaran dan klik button lanjutkan pesanan setelah itu akan masuk ke form pemesanan, form tersebut berisi : nama, nama lengkap, alamat, kota, provinsi, pengiriman, tanggal, telepon, email. Setelah biodata diisi, selanjutnya klik button kirim. Selanjutnya muncul transfer melalui rekening, di transfer melalui rekening ada total dan biaya pengiriman dan klik Button kirim pesanan barang, selanjutnya ada pemberitahuan "Data Anda sudah terkirim".

5) Halaman Informasi

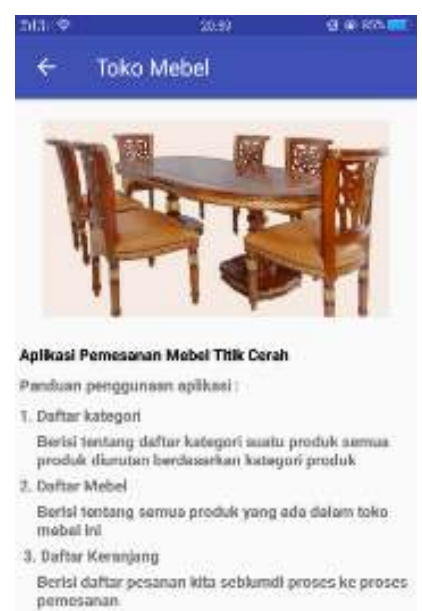

Gambar 10 Halaman Informasi

Selanjutnya akan muncul halaman informasi. Halaman yang berisi panduan penggunaan aplikasi penjualan mebel.

6) Halaman Profil 


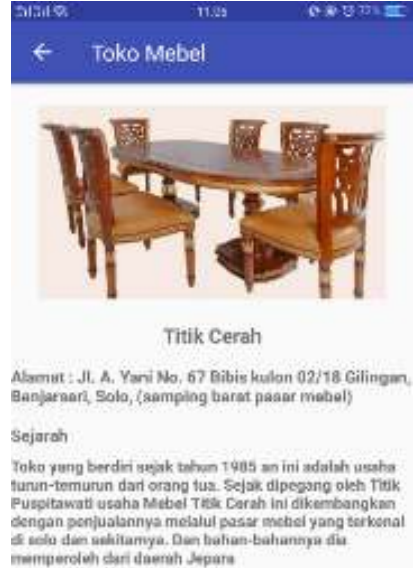

Gambar 11 Halaman Profil

Pada halaman profil berisi alamat, dan sejarah dari toko mebel.

b. Antar muka halaman admin berbasis web

1) Halaman Login Admin pada Web, dapat dilihat pada gambar dibawah ini:

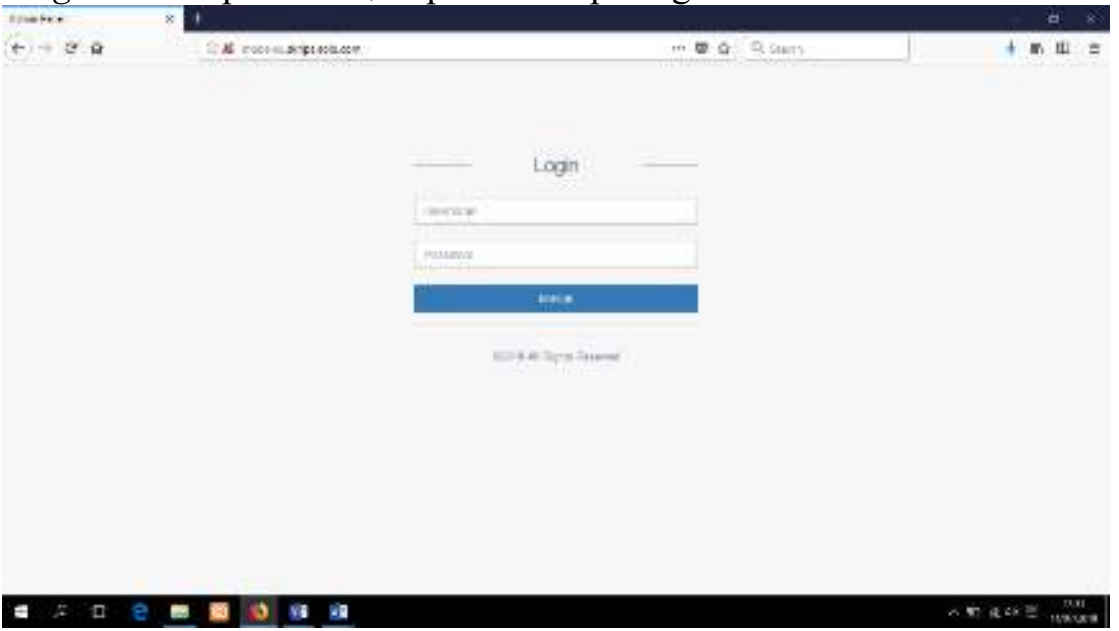

Gambar 12 Halaman Login Admin pada Web

Admin harus memasukkan username dan password lalu klik tombol masuk. Jika username dan password benar maka sistem akan menampilkan halaman beranda admin pada web. Jika username dan password salah maka admin tidak dapat masuk pada halaman beranda admin.

2) Halaman Beranda Admin di Web

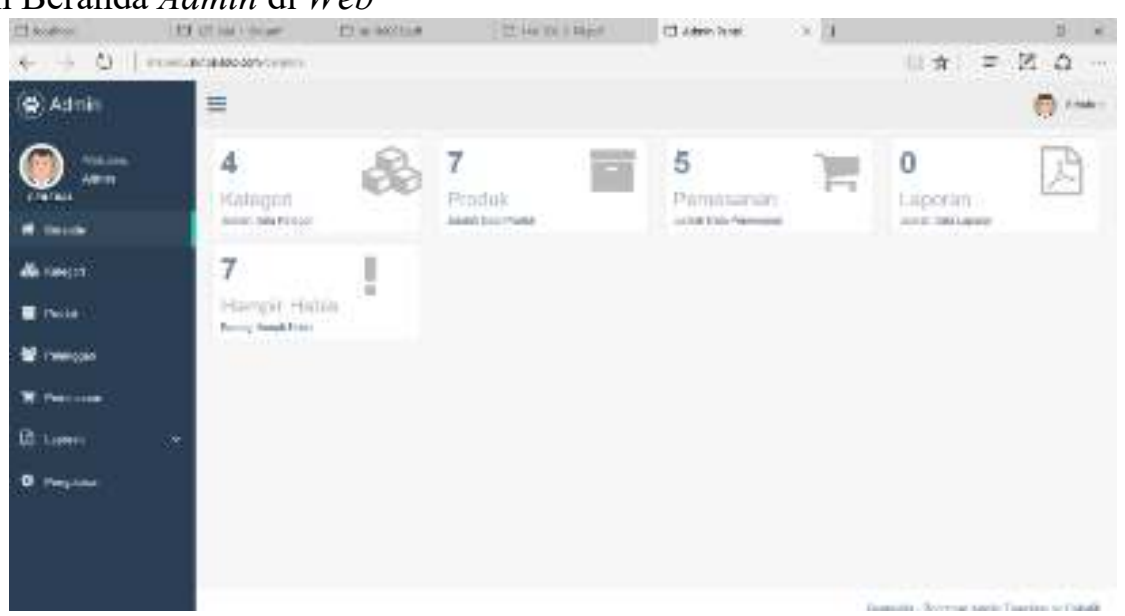


Gambar 13 Halaman Beranda Admin di Web

Apabila proses login sudah berhasil, maka sistem akan menampilkan halaman beranda admin, menu yang akan di tampilkan pada beranda ada empat macam, yaitu menu mengelola kategori, menu mengelola produk, menu mengelola pemesanan dan laporan, dan dapat pemberitahuan kalau barang hampir habis. Dan selanjutnya adalah admin klik menu data kategori, maka akan tampil gambar kategori.

3) Halaman Data kategori

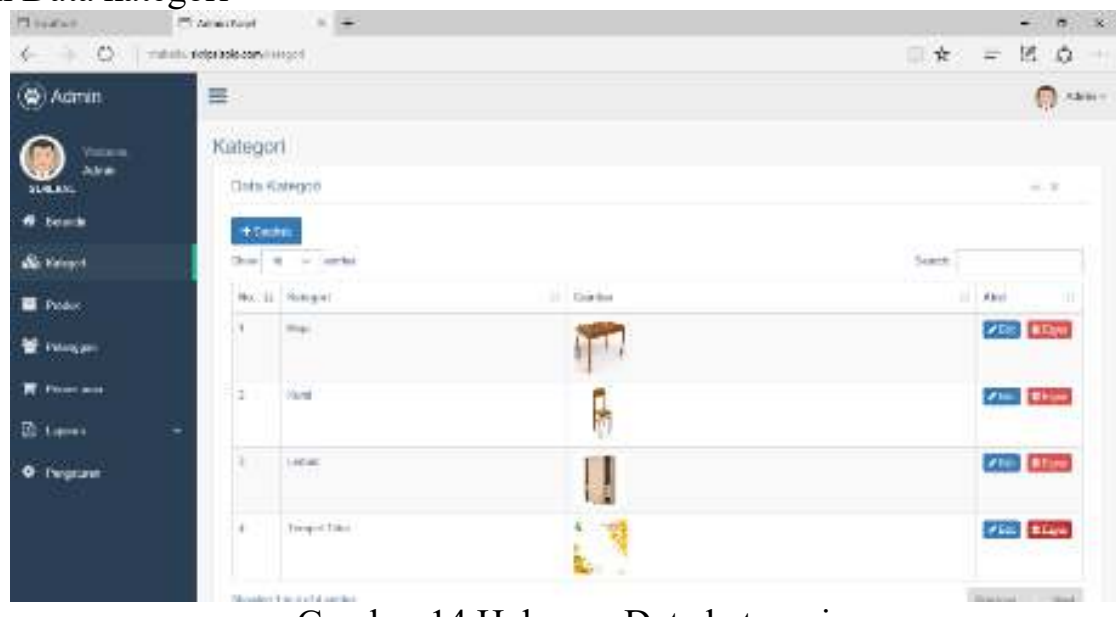

Gambar 14 Halaman Data kategori

Setelah masuk pada halaman data kategori, admin dapat menambah data kategori dengan cara klik tombol tambah data maka akan muncul form tambah, dapat mengedit atau mengubah data kategori dengan cara klik tombol edit, dapat menghapus data kategori dengan cara klik tombol hapus.

4) Halaman Data Produk

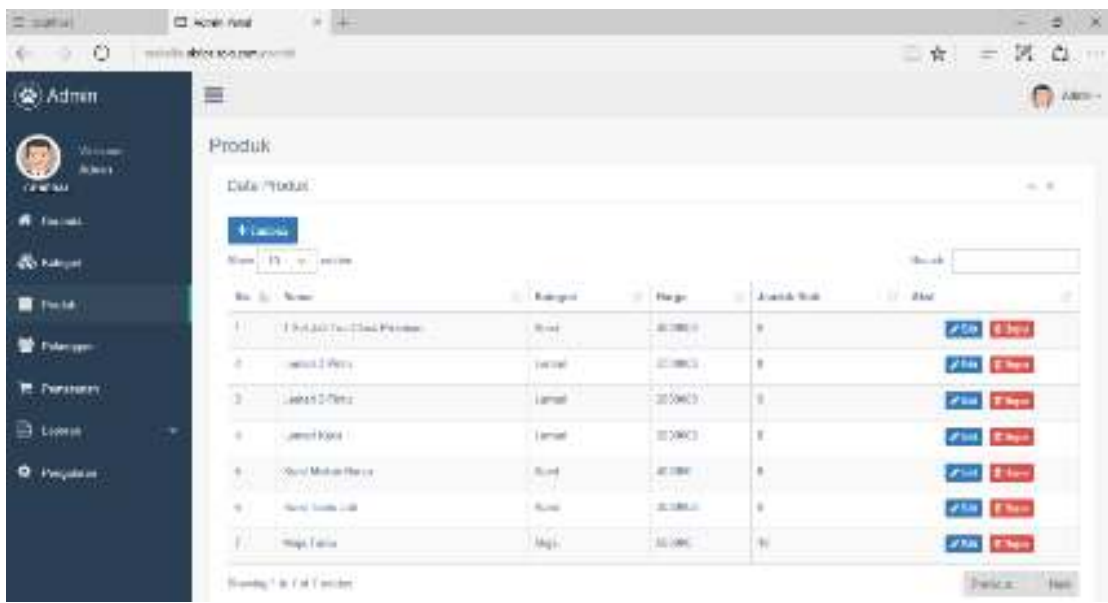

Gambar 15 Halaman Data Produk

Selanjutnya admin bisa melihat produk di halaman data produk secara detail. Jika admin ingin menambah data produk, maka klik button warna biru tambah produk. Admin dapat melakukan dua aksi yaitu mengedit data produk dengan cara klik button edit warna biru maka akan muncul halaman edit data produk dan dapat menghapus data produk dengan cara klik tombol hapus.

5) Halaman Laporan Data Produk 


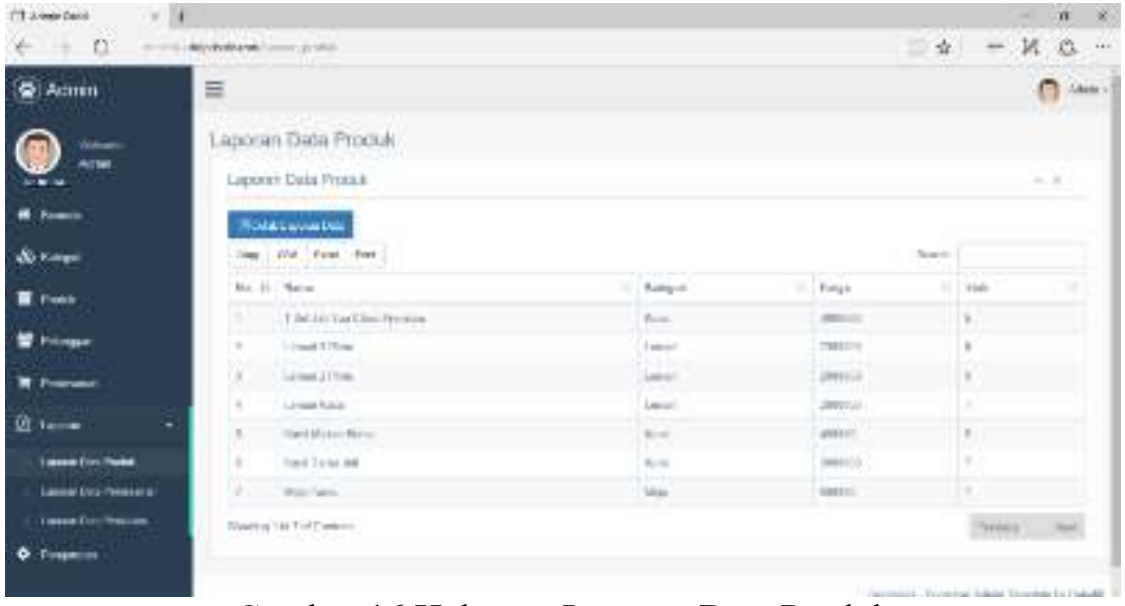

Gambar 16 Halaman Laporan Data Produk

Selanjutnya admin melihat dan mengecek laporan produk dalam halaman laporan data produk. Admin dapat mencetak laporan data produk dengan cara klik tombol warna biru.

6) Halaman Hasil Laporan Data Produk

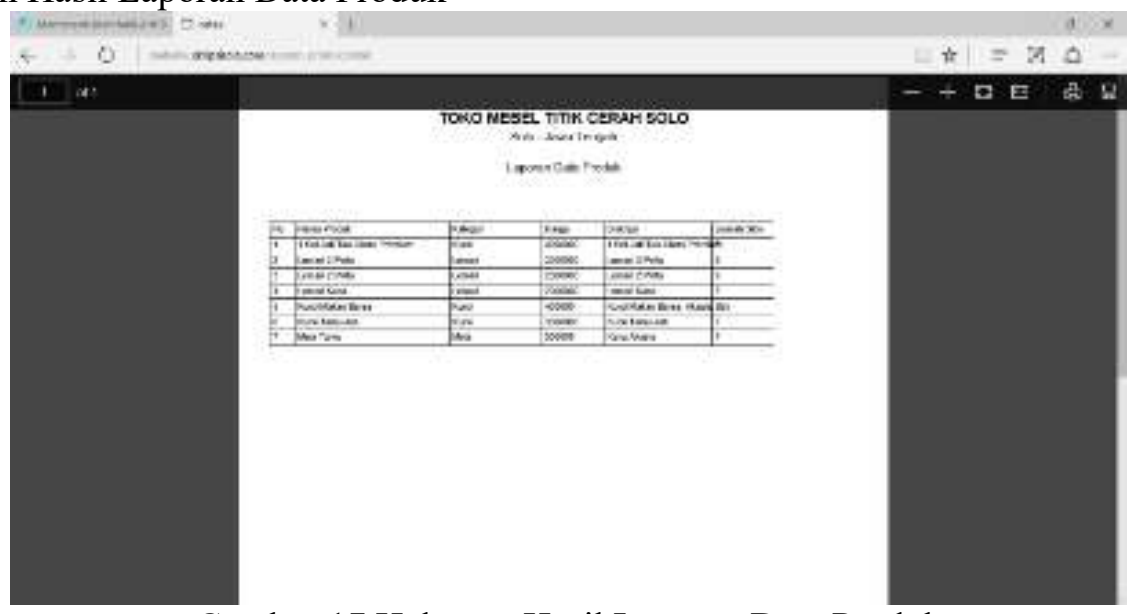

Gambar 17 Halaman Hasil Laporan Data Produk

Selanjutnya admin dapat melihat hasil laporan data produk, klik cetak laporan data maka akan muncul hasil laporan data produk.

7) Halaman Laporan Data Pemesanan

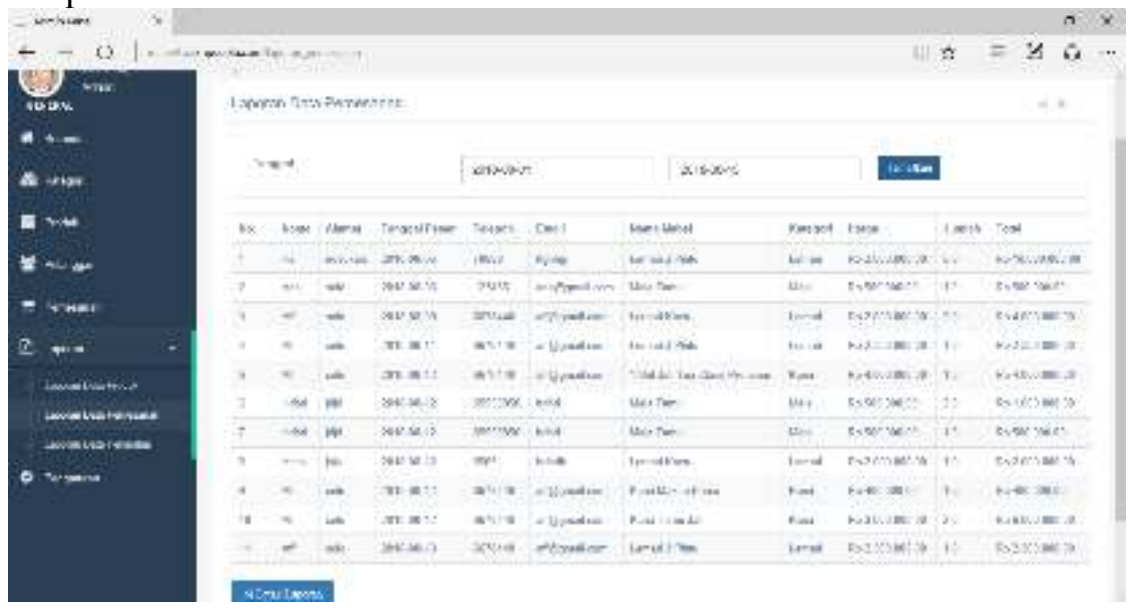

Gambar 18 Halaman Laporan Data Pemesanan

8) Halaman Hasil Laporan Data Pemesanan 


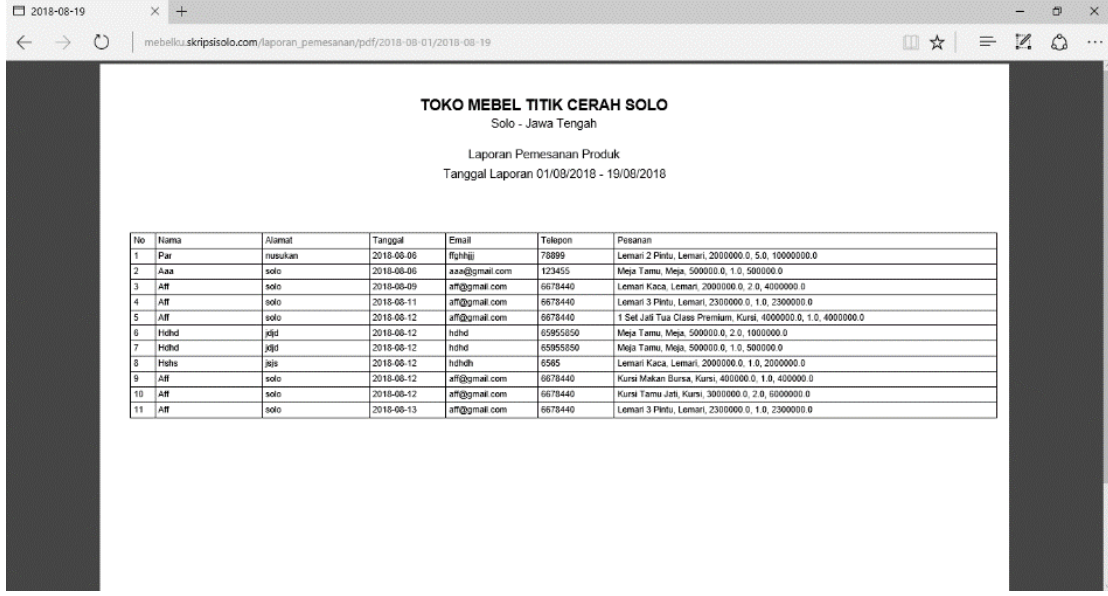

Gambar 19 Halaman Hasil Laporan Data Pemesanan

9) Halaman Laporan Data Penjualan

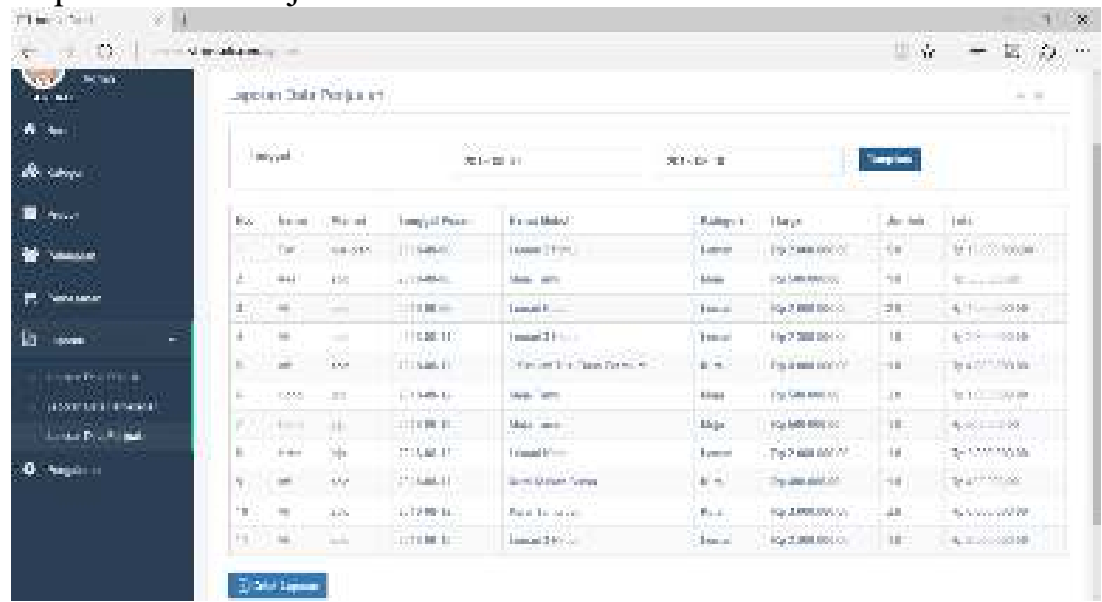

Gambar 20 Halaman Laporan Data Penjualan

10) Halaman Hasil Laporan Data Penjualan

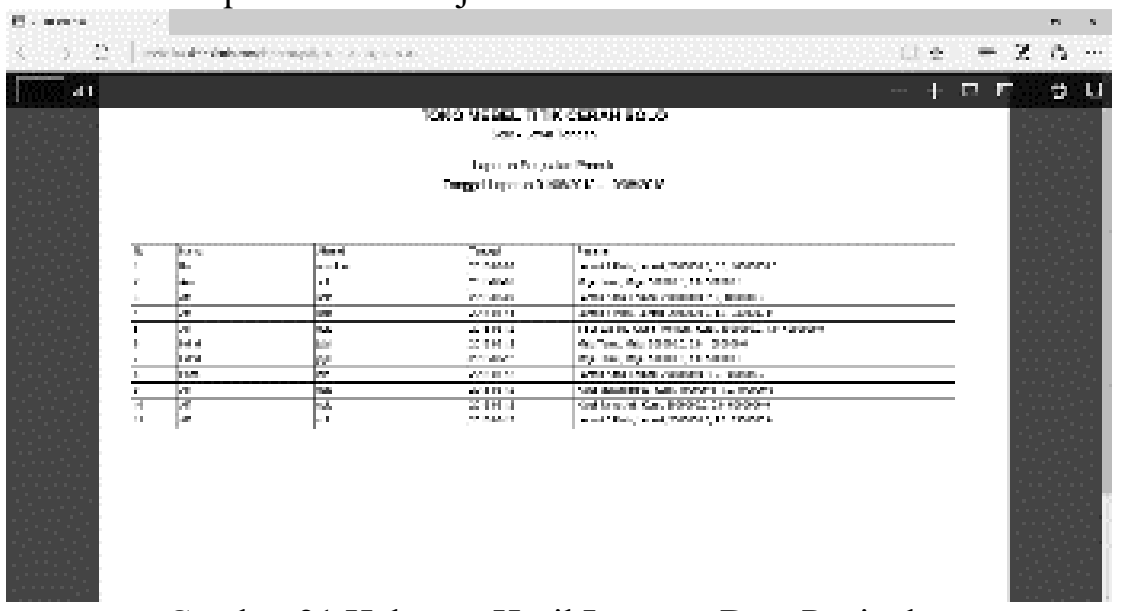

Gambar 21 Halaman Hasil Laporan Data Penjualan

Selanjutnya admin dapat melihat hasil laporan data pemesanan, klik cetak laporan data maka halaman hasil laporan data pemesanan.

11) Halaman Data Pengguna 


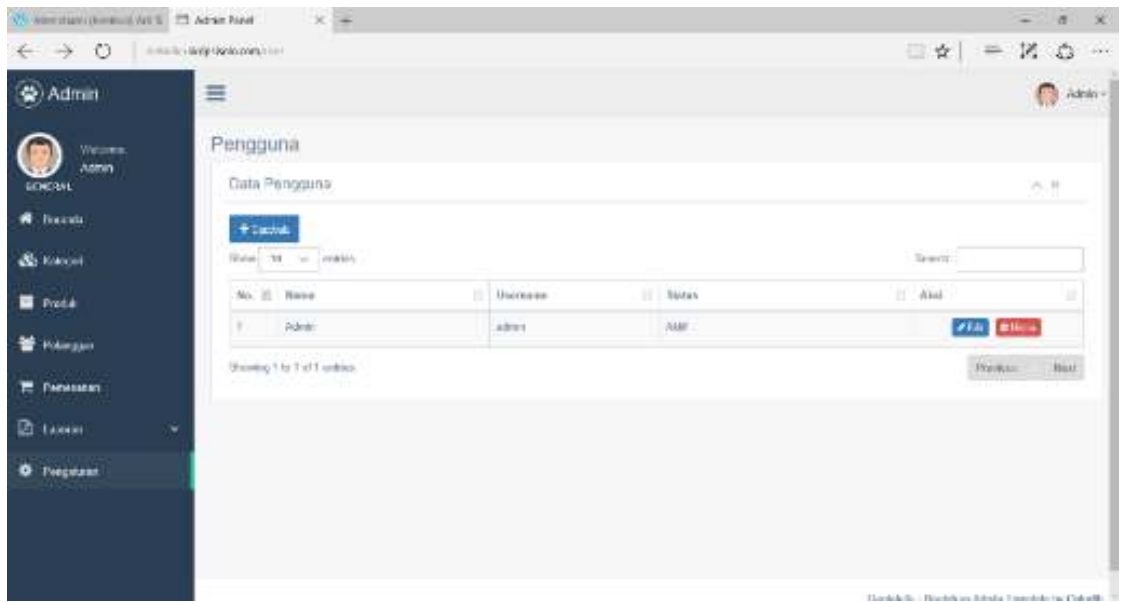

Gambar 22 Halaman Data Produk

Selanjutnya admin bisa melihat pengguna di halaman data pengguna secara detail. Jika admin ingin menambah data pengguna, maka klik button warna biru tambah produk Admin dapat melakukan dua aksi yaitu mengedit data pengguna dengan cara klik button edit warna biru maka akan muncul halaman edit data produk dan dapat menghapus data pengguna dengan cara klik tombol hapus.

\section{KESIMPULAN}

Hasil perancangan Aplikasi Android Penjualan Mebel Titik Cerah terdiri dari menggunakan Flowchart, UML (Unified Modeling Language) yang tediri dari Usecase Diagram, Activity Diagram, Sequence Diagram, Class Diagram, dan Realitions Between Tables, sedangkan untuk metode pengembangan sistem menggunakan Metode Waterfall. Pengembangan sistem menggunakan Bahasa pemrograman pendukung Android Studio Versi 3.1., PHP, Java dan MySQL sebagai pengolahan database. Sistem ini bisa melakukan pengolahan data kategori, produk, form pemesanan, laporan penjualan. Adanya Aplikasi Android Penjualan Mebel Titik Cerah memberikan media baru lagi untuk masyarakat untuk menyediakan penjualan mebel menggunakan aplikasi. Setelah itu juga dilengkapi dengan data pelanggan untuk mengetahui data pelanggan yang sering membeli mebel, tanpa mengingat dahulu pelanggan membeli mebel yang apa. Hasil penelitian ini adalah membuat suatu Aplikasi Android Penjualan Mebel Titik Cerah yang dapat membantu masyarakat untuk membeli mebel dengan mudah.

\section{SARAN}

Diharapkan nantinya aplikasi android ini dikembangkan untuk pembayarannya secara Online dan diharapkan untuk menambahkan pesan di aplikasi android penjualan mebel untuk konsumen ke pemilik. Dari Web diharapkan bisa menambahkan multi fungsi.

\section{DAFTAR PUSTAKA}

[1] A.S Rosa dan Salahuddin M, 2011. Modul Pembelajaran Rekayasa Perangkat Lunak (Terstruktur dan Berorientasi Objek), Modula, Bandung.

[2] Akbar, Husaini Usman Dan Purnomo Setiady (2000) Metodologi Penelitian Sosial, Jakarta: Bumi Aksara.

[3] Al Fatta, Hanif. 2007. Analisi dan Perancangan Sistem Informasi. Yogyakarta : Andi.

[4] Android Studio, http://developer.android.com/tools/studio/index.html, diakses pada tanggal 21 Juli 2018. 
[5] Asropudin Pipin, 2013. Kamus Teknologi Informasi. Bandung: Titian Ilmu.

[6] Chan, Syahrial. 2017. Membuat Aplikasi Database dengan Power Builder 12.6 MySQL. Jakarta. PT Elex Media Komputindo.

[7] Hasanah, Uswatun, dkk. 2016. Model Aplikasi Penjualan Furniture Pada Mebel Rahayu Di Kuala Kapuas. http://ojs.stmikbanjarbaru.ac.id/index.php/jutisi/article/viewFile/127/118 diakses tanggal 30 Oktober 2017

[8] Indrajani. 2015. Database Design (Case Study All in One). Jakarta: PT Elex Media Komputindo.

[9] Iskandaria. 2012. Contoh Pengujian Black Box. http://kafegue.com/contoh-pengujianblack-box-testing/

[10] Janner Simarmata. 2009. Perancangan Basis Data. Andi. Yogyakarta.

[11] Jeckson Silitonga, Eka Suswaini, ST, MT 2, dan HendraKurniawan, S.Kom.,M.Sc.Eng3. 2013. Pendaftaran Mahasiswa Baru Berbasis Mobile (Studi Kasus : Universitas Maritim Raja Ali Haji) . Riau.

[12] Jogiyanto, Hartono. 2005. Analisis dan Desain Sistem Informasi, Edisi III.

[13] Kadir, Abdul. 2002. Dasar Pemrograman WEB Dinamis Menggunakan PHP Edisi Revisi. Yogyakarta. C.V Andi Offset

[14] Kadir, Abdul. 2008. Dasar Pemrograman WEB Dinamis Menggunakan PHP. Yogyakarta. C.V Andi Offset

[15] Kotler, Philip., dan Gary Armstrong., 2004, Dasar-DasarPemasaran, Edisi kesembilan, Jilid 1, dialihbahasakan oleh Alexander Sindoro, Jakarta: Indeks

[16] Ladjamuddin, A.-B.B. (2006). Rekayasa Perangkat Lunak cet-keII. Yogyakarta:GRAHA ILMU.

[17] Marjito dan Gina Thesaria. 2016. Aplikasi Penjualan Online Berbasis Android (Studi Kasus: Di Hoko Hoax Merch). jurnal.stmikmi.ac.id/index.php/jcb/article/download/144/168 diakses tanggal 30 Oktober 2017

[18] Munawar. 2005. Pemodelan Visual dengan UML.Yogyakarta : Penerbit Graha Ilmu.

[19] Nugroho, Adi. 2005.Rational Rose untuk Pemodelan Berorientasi Objek. Bandung : Penerbit Informatika.

[20] Pressman, R.S. (2010), Software Engineering : a practitioner's approach, McGraw Hill, New York, 68.

[21] Saputra, A dan Agustin, F. 2012. Membangun Sistem Aplikasi E - Commerce dan SMS. PT Elex Media Komputindo, Jakarta.

[22] Shihab. 2011. Metode White Box dan Black Box Testing. http://rijjasihabuddin. blogspot.com/2014/03/metode-white-box-dan-black-box-testing.html.

[23] Sugiyono. 2013. Metode. Penelitian Pendidikan Pendekatan Kuantitatif, Kualitatif, dan R\&D. Bandung: Alfabeta.

[24] Supardi, Ir. Yuniar. 2017. "Koleksi Program Tugas Akhir dan Skripsi dengan Android" . Jakarta : PT Elex Media Komputindo.

[25] Suryadi, Matius Tomy. 2014. The Best Android Apps for Chatting. Yogyakarta : CV Andi Offset.

[26] Sutabri, Tata 2012. Analisis Sistem Informasi. Andi. Yogyakarta

[27] Wahana Komputer dan Andi. 2015. Membangun Sistem Informasi dengan Java Netbeans dan MySQL. Wahana Komputer Semarang: CV Andi Offset.

[28] Wibowo, Arif. 2014. Pembuatan Sistem Informasi Penjualan Furniture Dan Electronic Pada Toko Joice Group. Diakses tanggal 21 Juli 2018. 